\title{
DUKUNGAN SOSIAL TERHADAP ANAK JALANAN DI RUMAH SINGGAH
}

\author{
Oleh: \\ Rivanlee Anandar, Budhi Wibhawa \& Hery Wibowo \\ Email: \\ (rivanlee@gmail.com; budhiwibhawa@gmail.com; hery_fortune@yahoo.com)
}

\begin{abstract}
ABSTRAK
Berbagai perubahan terjadi pada anak jalanan di rumah singgah, baik perubahan yang berhubungan dengan kondisi fisik maupun berhubungan dengan kondisi lingkungan. Perubahanperubahan yang terjadi pada anak jalanan dipengaruhi oleh apa yang mereka terima di rumah singgah. Perubahan masa dari yang sepenuhnya di jalan sampai sebagian di panti tentu tak mudah bagi anak jalanan, tak heran jika beberapa anak mengalami kejenuhan atau stress saat di rumah singgah.

Untuk mengatasi dan menyesuaikan diri dengan berbagai perubahan tersebut, anak jalanan di rumah singgah membutuhkan dukungan dari orang-orang di sekitarnya. Dukungan ini yang disebut dukungan sosial, dan orang-orang yang memberi dukungan disebut sumber dukungan.

Studi kepustakaan menyatakan bahwa dukungan sosial akan dapat membantu mencegah efek negatif karena adanya stress apabila terjadi kesesuaian antara harapan dan penerimaan dukungan sosial bagi individu, penerima dukungan. Demikian pula dukungan sosial dari staf serta lingkungan rumah singgah akan dapat mencegah efek negatif karena keterkejutan budaya pada anak yang biasa di jalanan. Oleh karena itu, peneliti merasa penelitian ini penting disamping untuk sumbangan perbaikan pada program yang diberikan lembaga juga diharapkan penelitian ini dapat memberi ide tentang pemberian dukungan sosial di lembaga lain

Pada penelitian ini juga hendak diteliti hambatan serta faktor pendukung pemberian dukungan sosial yang ada di lembaga. Hal ini dilakukan karena persepsi individu, penerima dukungan, sebelumnya berada dalam lingkungan yang beda dan jauh dari dukungan sosial yang membuat dirinya baik.
\end{abstract}

Kata kunci: anak jalanan, dukungan sosial, rumah singgah

\begin{abstract}
Numerous changes occurred in street children, both a layover at home alterations related to the physical condition and related to environmental conditions. The changes that occurred on the street children are influenced by what they receive in guesthouses. The change from being fully on the road to some parlors is certainly not easy for street children, no wonder some kids experiencing Burnout or stress during a layover at home.

The study stated that social support libraries will be able to help prevent negative effects due to stress in the event of the alignment between hope and receipt of social support for the individual, the recipient of support. Similarly, social support from staff and layover home environment will be able to prevent the negative effects because of cultural shock in children are commonplace in the streets. Therefore, researchers feel this research is important in addition to donations of improvements on the given program Agency also expected this research can give an idea about giving social support in other institutions.

The study also try to find factor inhibitor and factors supporting the granting of social support that exists in the Agency. This is due to the perception of the individual, the recipient of
\end{abstract}


the support, the previous being in a different environment and away from the social support that makes them good.

\section{A. Latar Belakang}

Berdasarkan data dari Kemensos yang dimuat di indonesia.ucanews.com, anak jalanan yang tersebar di Indonesia ada sekitar 420.000. Perkembangan pesat anakanak jalanan di berbagai sudut jalan, selain memprihatinkan dari segi kemanusiaan, di saat yang sama juga melahirkan permasalahan sosial baru yang cukup meresahkan. Kendati disadari bahwa tidak semua anak jalanan melakukan tindakantindakan yang sampai mengganggu ketertiban umum, namun tidak dapat dipungkiri bahwa ada sebagian di antara mereka yang merusak citra anak jalanan secara keseluruhan dengan tindakan mereka yang mengarah pada perilaku kriminal, seperti kegiatan premanisme kecil-kecilan.

Anak-anak menjadi anak jalanan karena berbagai alasan. menurut Soetji Andari dalam bukunya tentang Pengkajian Berbagai Tindak Kekerasan dan Upaya Perlindungan Anak Jalanan mengemukakan bahwa penyebab anak turun ke jalan adalah Meningkatnya skala dan kompleksitas masalah psikososial yang dialami keluarga, seperti keterpisahan orang tua, stress yang dialami orang tua, rendahnya kemampuan dalam pengasuhan dan perawatan anak, kekerasan dalam keluarga, dan lain-lain, Rendahnya tingkat kemampuan ekonomi keluarga yang mengakibatkan tidak mampunya keluarga memenuhi kebutuhan anak, Mengakarnya nilai budaya yang tidak berpihak pada anak, yang membawa kecenderungan pada pengabaian terhadap hak-hak anak.

Menurut data Kemensos pada situs http://pksa.kemsos.go.id/, di Jakarta, anak jalanan ada sekitar 8000 orang. Kalau keadaannya sudah segenting ini maka institusi atau lembaga dari negara maupun swasta berhak bergerak untuk memberikan pelayanan baik pendidikan, kesehatan, hingga kasih sayang agar anak-anak jalanan dapat mengerti tentang baik buruk kehidupan dan perilakunya dapat diterima di masyarakat. Sebagaimana di jelaskan dalam UU No. 23 tahun 2002 tentang Perlindungan Anak Bab IV bagian kettiga pasal 25 yang berbunyi: "Tanggung jawab masyarakat terhadap perlindungan anak dilaksanakan melalui kegiatan peran masyarakat dalam penyelenggaraan perlindungan anak"

Bentuk partisipasi swasta atau masyarakat dalam memberdayakan anak jalanan adalah dengan adanya rumah singgah. Rumah singgah adalah salah satu bentuk pelayanan sosial. Rumah singgah adalah suatu wahana yang dipersiapkan sebagai perantara antara anak jalanan dan pihak-pihak yang membentu mereka (Modul Pelatihan Pimpinan Rumah Singgah, 2000:96). berdasarkan pengertian tersebut rumah singgah merupakan proses informal yang memberikan suasana sosial kepada anak jalanan terhadap sistem nilai dan norma yang berlaku di masyarakat setempat.

Menurut Depsos RI dalam Journal.uny.ac.id, rumah singgah hanya sebagai perantara anak jalanan dengan pihak-pihak yang akan membantu mereka sebagai proses informal yang memberikan suasana pusat realisasi dan sosialisasi anak jalanan terhadap sistem nilai dan norma masyarakat. Secara umum tujuan dibentuknya rumah singgah adalah membantu anak jalanan dalam mengatasi masalah-masalah dan menemukan alternatif untuk pemenuhan kebutuhan hidupnya. Kegiatan awal dari aktivitas rumah singgah adalah penjangkauan. Kegiatan ini dilakukan oleh lembaga yang melayani anak secara langsung untuk mengetahui keadaan anak di lapangan dan mempersiapkan metode intervensi apa yang tepat diberikan pada anak. Berikutnya, anak yang hidup di jalanan diberikan fasilitas rumah, rumah inilah yang disebut sebagai rumah singgah tempat untuk mempermudah intervensi lembaga kepada anak-anak jalanan.

Melihat kerasnya kehidupan yang dihadapi oleh anak-anak dari keluarga prasejahtera dengan gizi buruk, sakit, cacat, putus sekolah, serta anak-anak yang terpaksa harus mengais rejeki di jalanan kota-kota besar seperti Jakarta, Dilts Foundation mencoba memberikan anak-anak kesempatan menjalani kehidupan yang lebih baik, sehat, aman, dan produktif melalui 
program-program pembelajaran dan mengorganisir kegiatan-kegiatan konkret yang bergerak di bidang pendidikan, pelayanan kesehatan, pelatihan keterampilan dan kerja sosial dengan komunitas miskin dan terpinggir.

Melalui rumah singgah, anak jalanan diharapkan dapat menyesuaikan diri dengan keadaan lingkungan fisik dan lingkungan sosial di rumah singgah. Selain itu, untuk dapat melalui serangkaian perubahan dan penyesuaian diri dengan baik di rumah singgah, anak jalanan membutuhkan dukungan dari orang-orang di sekitarnya. Dukungan ini berupa dukungan sosial yang mana diartikan sebagai daya dorong dari lingkungan sekitar untuk mendukung individu melakukan perubahan. Dukungan sosial ini memiliki dampak luar biasa dengan memberikan efek positif individu (Gottlieb, 1987; Wartman dan Loftus, 1992).

Namun, sebagaimana umumnya, anak jalanan menghabiskan keseharian hidupnya di jalanan. Kehidupan yang berbeda dengan anak pada umumnya. Kehidupan anak jalanan bisa dibilang keras, kotor, dan melelahkan. Dengan berbagai macam pengalaman yang terjadi di jalanan, pikiran pada anak jalanan akan terdistraksi oleh keadaan jalanan seperti kekerasan, pencurian, dan tindak kekerasan lainnnya. Sehingga dari pengalaman yang membuat mereka berpikir seperti itu berdampak pada sikap dan perilakunya sehari-hari. Jadi, "tinggal" di rumah singgah bukanlah hal yang mudah bagi anak jalanan. Perubahan lingkungan dari lingkungan sebelumnya ke lingkungan rumah singgah dapat membuat jenuh bagi anak jalanan. Melalui rumah singgah, anak jalanan diharapkan dapat menyesuaikan diri dengan keadaan lingkungan fisik dan lingkungan sosial di rumah singgah.

Selain itu, untuk dapat melalui serangkaian perubahan dan penyesuaian diri dengan baik di rumah singgah, anak jalanan membutuhkan dukungan dari orang-orang di sekitarnya. Dukungan ini berupa dukungan sosial yang mana diartikan sebagai daya dorong dari lingkungan sekitar untuk mendukung individu melakukan perubahan. Dukungan sosial ini memiliki dampak luar biasa dengan memberikan efek positif individu (Gottlieb, 1987; Wartman dan Loftus, 1992). Dukungan sosial dapat membantu individu untuk mencegah efek negatif karena stress. Dalam penelitian ini, sumber dukungan yang diperoleh anak jalanan dapat berasal dari berbagai pihak, misalnya dari sesama anak jalanan lain; keluarga; dari pegawai rumah singgah; serta dari orang-orang yang tinggal di sekitar rumah singgah.

Pada penelitian ini, dukungan sosial yang ingin dilihat adalah yang berasal dari rumah singgah Dilts Foundation. Karena dalam hal ini, rumah singgah memiliki tanggung jawab yang lebih besar bagaimana membuat sikap dan perilaku anak jalanan-yang diasumsikan berseberangan dengan norma yang ada di masyarakat- perilakunya dapat diterima oleh orang lain.

Berangkat dari latar belakang tersebut, penelitian ini difokuskan untuk melihat dukungan sosial yang diberikan pada anak jalanan binaan rumah singgah dilts foundation. Secara lebih dalam lagi, dukungan sosial dalam bentuk apa saja yang diberikan oleh rumah singgah Dilts Foundation sehingga mampu menjadikan anak jalanan binaannya dapat diterima di masyarakat luas. Penelitian ini bersifat studi deskriptif dengan tujuan untuk mengindentifikasi dan menggambarkan dukungan sosial yang diterima anak jalanan binaan rumah singgah dilts foundations. Penelitian ini diharapkan dapat menyumbangkan tambahan ide dan sebagai bentuk contoh dari lembaga pelayanan sosial

\section{B. Metode (Methods), Hasil dan Pembahasan (Results and Discussion)}

Dalam penelitian ini penulis menggunakan metode kualitatif. Penelitian kualitatif adalah metode yang menggambarkan dan menjabarkan temuan di 
lapangan. Metode kualitatif hanyalah memaparkan situasi atau peristiwa. Penelitian degan metode ini tidak mencari atau menjelaskan hubungan, tidak menguji hipotesis atau membuat prediksi.

Menurut Sugiyono (2011:15), metode penelitian kulitatif adalah metode penelitian yang berlandaskan pada filsafat postpositivisme, digunakan untuk meneliti pada kondisi obyek yang alamiah, (sebagai lawannya eksperimen) dimana peneliti adalah sebagai instrument kunci, pengambilan sampel sumber data dilakukan secara purposive dan snowball, teknik pengumpulan dengan trianggulasi (gabungan), analisis data bersifat induktif/kualitatif, dan hasil penelitian kualitatif lebih menekankan makna dari pada generalisasi.

Departemen Sosial RI dalam Fery Johanes (2007) "Penanganan Anak Jalanan di Indonesia" mendefinisikan anak jalanan sebagai anak yang menggunakan sebagian waktunya dijalanan baik untuk bekerja maupun tidak yang terdiri dari anak-anak yang masih mempunyai hubungan dengan keluarga atau sudah putus hubungan dengan keluarga dan anak-anak yang hidup mandiri sejak masa kecil karena kehilangan keluarga atau orang tuanya. Mereka kerap kali menghabiskan waktunya untuk bekerja, entah untuk kebutuhan pribadi entah untuk membantu keluarganya. Pekerjaan yang biasa dilakukan anak jalanan sangat beragam. Mulai dari berjualan tisu, menyediakan jasa menyemir sepatu, sampai mengemis. Kebanyakan dari anak jalanan dapat ditemukan di persimpangan jalan karena terdapat lampu merah tempat kendaraan berhenti, tapi ada juga yang bergerak di pasar tradisional dan jembatan. Tidak semua anak yang tinggal atau bekerja di jalanan disebut anak jalanan. Menurut Odi Shalahudin dalam bukunya "Anak Jalanan Perempuan", seseorang yang berumur di bawah 18 tahun yang menghabiskan sebagian atau seluruh waktunya di jalanan dengan melakukan kegiatan-kegiatan guna mendapatkan uang atau guna mempertahankan hidupnya itulah yang disebut sebagai anak jalanan.

Anak jalanan yang bekerja dan mencari uang di jalanan terbagi ke dalam tiga tipologi atau kelompok, seperti yang dikemukakan oleh Sri S. Hariadi dan Suyanto (1999: 78-82), yaitu:

\section{Children on the Street}

Anak yang bekerja di jalan merupakan mereka yang menghabiskan sebagian besar waktunya di jalanan atau di tempat umum lainnya untuk bekerja dan penghasilannya digunakan untuk membantu keluarganya. Anak-anak tersebut mempunyai kegiatan ekonomi (sebagai pekerja anak) di jalan dan masih mempunyai hubungan yang kuat dengan orang tua mereka.

2. Children of the street

Anak-anak yang hidup di jalan merupakan mereka yang menghabiskan sebaian besar waktunya di jalan atau ditempat umum lainnya, tetapi hanya sedikit yang digunakan untuk bekerja. Mereka jarang berhubungan dengan keluarganya. Beberapa di antara mereka hidup di sembarang tempat dan tidak memiliki rumah tinggal. Banyak di antara mereka adalah anak-anak yang karena suatu sebab lari atau pergi dari rumah. Anak-anak seperti ini rawan terhadap perilaku menyimpang, baik emosional, fisik maupun seksual.

3. Children in the Street

Merupakan anak-anak yang menghabiskan seluruh waktunya di jalanan yang berasal dari keluarga yang hidup atau tinggalnya juga di jalanan.

Berangkat dari tipologi yang telah disebutkan, selanjutnya muncul karakteristik atau sifat-sifat yang menonjol dari anak jalanan, diantaranya adalah (1) pakaian yang lusuh, kotor, begitu pula pada tubuh dan wajahnya (2) mandiri dalam artian tidak menggantungkan hidup kepada orang lain dan tidur di mana saja (3) menganggap orang yang tidak hidup di jalanan sebagai orang yang dapat dimintai uang (4) tidak memiliki rasa takut berhadapan dengan siapa saja (6) hasrat untuk belajar yang kurang.

Pada artikel "Pengkajian Berbagai Tindak Kekerasan dan Upaya Perlindungan Anak Jalanan", Soetji Andari menjelaskan bahwa secara umum anak jalanan yang ada di daearh perkotaan memiliki kesamaan ciri, antara lain (1) berada di tempat umum selama 3 sampai 24 jam sehari. (2) berpendidikan rendah. (3) berasal dari 
keluarga tidak mampu. (4) melakukan aktivitas ekonomi.

Tak akan ada akibat jika tak ada sebab. Fenomena anak jalanan adalah efek domino dari beberapa faktor. Seperti ketimpangan penduduk, tingkat kesejahteraan yang rendah. Pengaruhpengaruh lain seperti psikologis, ekologis, sosial budaya, dan pendidikan juga kerapkali memengaruhi anak turun ke jalan.

Menurut Dirjen Pelayanan dan Rehabilitasi Sosial, Depsos RI, 2002:4), faktor penyebab munculnya anak jalanan antara lain adalah berkaitan dengan kondisi seperti:

1. Meningkatnya skala dan kompleksitas masalah psikososial yang dialami keluarga, seperti keterpisahan orang tua, stress yang dialami orang tua, rendahnya kemampuan dalam pengasuhan dan perawatan anak, kekerasan dalam keluarga, dan lain-lain

2. Rendahnya tingkat kemampuan ekonomi keluarga yang berakibat tidak mampunya keluarga memenuhi kebutuhan anak

3. Budaya orang tua yang kerap mengabaikan hak-hak anak sehingga anak merasa kurang kasih sayang

Selain itu, Tata Sudrajad dalam Wahyu Nurhajadmo (1999, 15), "Seksualitas Anak Jalanan" menyatakan ada tiga penyebab munculnya fenomena anak jalanan

1. Tingkat mikro (immediate causes), yakni faktor-faktor yang berhubungan dengan situasi anak dan keluarganya; (1) sebab dari keluarga: ditelantarkan, ketidakmampuan orang tua menyediakan kebutuhan dasar, ditolak orang tua, salah perawatan, adanya kekerasan di rumah, kesulitan berhubungan dengan keluarga, dan terpisah dari orang tua. (2) sebab dair anak: lari dari keluarga, disuruh bekerja baik karena masih sekolah atau sudah putus sekolah, bermain-main diajak teman.

2. Tingkat meso (underlying causes), yakni faktor-faktor yang ada di masyarakat tempat anak dan keluarga berada. (1) masyarakat miskin: anak-anak adalah aset untuk membantu peningkatan ekonomi keluarga, anak-anak diajarkan bekerja meski hal ini dapat mengakibatkan mereka drop out dari sekolah. (2) pada masyarakat lain, urbanisasi menjadi kebiasaan dan anakanak mengikuti kebiasaan tersebut. (3) penolakan masyarakat sekitar terhadap diri anak.

3. Tingkat makro (basic causes), yakni faktor-faktor yang besar untuk menjadi anak jalanan. (1) ekonomi: adanya peluang pekerjaan sektor informal yang tidak terlalu membutuhkan modal keahlian, tuntutan ekonomi memaksa mereka harus lama di jalan dan meninggalkan bangku sekolah, dan ketimpangan desa dengan kota yang mendorong urbanisasi. (2) pendidikan: biaya sekolah yang tinggi, perilaku guru yang diskriminatif, ketentuan teknis dna birokratis yang mengalahkan kesempatan belajar. (3) belum seragamnya unsur-unsur pemerintah dalam memandang permasalahan anak jalanan, antara sebagai sebuah kelompok yang memerlukan perawatan dan yang menganggap anak jalanan sebagai trouble maker)

\section{Dukungan Sosial}

Cobb memberi definisi dukungan sosial sebagai cara untuk mengarahkan individu bahwa ia diperhatikan, dicintai, dihargai, dan meyakinkan bahwa ia adalah bagian dari satu kelompok yang saling memiliki tanggung jawab. Setiap informasi dari lingkungan sosial yang menyebabkan persepsi individu bahwa ia diterima dengan penerimaan positif, penghargaan atau perhatian merupakan ekspresi dari dukungan sosial.

Sedangkan, House (dalam Gottlieb,
1988) mendefinisikan dukungan sosial
sebagai:
"an interpersonal transaction involving
one or more of the following: (1)
emotional concern (liking, love,
empathy), (2) instrumental aid (good or
services), (3) information (about
environment), (4) appraisal (information
relevant to the self-evaluation" (p. 39)"

House melihat dukungan sosial sebagai transaksi interpersonal yang melibatkan satu atau lebih komponen, yaitu perhatian emosional (suka, cinta, empati), bantuan instrumental (barang atau jasa), informasi 
(mengenai lingkungan) atau penilaian (informasi yang relevan terhadap penilaian diri). Jadi, ketika ada salah satu komponen yang bekerja dalam transaksi interpersonal, sudah bisa dikatakan sebagai dukungan sosial.

Definisi mengenai dukungan sosial juga dijelaskan oleh Weiss (dalam Sarason, 1983), ia menjelaskan ada 6 dimensi dari dukungan sosial, yaitu intimacy, social integration, nurturance, worth, alliance, and guidance.

Dari beragam penjelasan ahli, dukungan sosial tak lain adalah kesediaan orang untuk mengarahkan, meyakinkan kepada individu bahwa ia tidak sendiri dengan menekankan bahwa ia dicintai, dihargai, diperhatikan, dan dapat meminta bantuan pada saat individu dalam kondisi yang tertekan.

Untuk menerapkan dukungan sosial itu sendiri dibutuhkan bentuk dari dukungan sosial. sejauh ini, bentuk dukungan sosial sangat beragam dari para ahli sesuai dengan bahan kajian mereka. Penulis akan memberikan rangkuman mengenai bentuk dukungan sosial dari Gottlieb dan Cobb, sebagai berikut:

\section{Emotional Support}

Dukungan emosi merupakan ekspresi kasih sayang dan rasa cinta dari orang-orang di sekitar individu (Cutrona, Cole, Colangelo, Assouline, dan Russel, 1994). Individu dapat mencurahkan perasaan, kesedihan ataupun kekecewaannya pada seseorang dan hal ini membuat individu yang menerima dukungan sosial tersebut merasa adanya keterikatan, kedekatan dengan pemberi dukungan sehinga menimbulkan rasa aman dan percaya. (Weiss, dalam Cutrona dan Russell, 1987; Elliot, Herrick, dan Witty, 1992).

Menurut ahli, bentuk dukungan emosi ini sangat penting dan dibutuhkan dalam kehidupan seseorang (Turner, 1983) dan dalam setiap perode kehidupan karena dukungan ini memberikan perhatian yang dalam dalam terhadap indvidu di mana individu dapat secara leluasa mencurahkan isi hatinya (Mirowsky dan Ross, 1989)

\section{Social Integration}

Menurut Felton dan Berry (1992), bentuk dukungan ini dapat terjadi bila indvidu merasa memperoleh teman yang menyenangkan sehingga ia dapat melakukan aktivitas bersama. Dengan adanya dukungan ini, individu merasa dirinya sebagai bagian dari kelompok tertentu dan kelompok tersebut memiliki kesamaan minat untuk melakukan kegiatan bersama dan hal ini dapat memenerikan rasa nyaman dan senang (Cutrona et al., 1994).

\section{Instrumental Support}

Dukungan ini berbentuk materi atau jasa yang diberikan oleh orang lain kepada individu sebagai penerima dukungan (Orford, 1992). Bantuan yang diberikan dapat berupa uang, barang kebutuhan sehari-hari, atau bantuan praktis, seperti memberikan fasilitas transportasi, membantu menyelesaikan pekerjaan rumah atau menyediakan waktu untuk bermain. Bantuan dalam bentuk ini penting bagi anak jalanan. Usia anak-anak membuat ia membutuhkan teman untuk mengekspresikan dirinya di depan orang lain

\section{Esteem Support}

Dengan dukungan ini, individu sebagai penerima dukungan merasa memiliki nilai terhadap dirinya karena adanya pengakuan dari orang lain atas kemampuannya dan kualitas personalnya (Cutrona et al., 1994, Felton dan Berry. 1992). Dengan adanya dukungan ini, individu merasa dihargai oleh orang disekitarnya atas apa yang telah dilakukannya. Dukungan ini dapat berbentuk pujian terhadap apa yang telah dilakukan individu atau juga penerimaan terhadap kekurangan individu.

\section{Informational Support}

Dukungan ini memungkinkan individu sebagai penerima dukungan untuk memperoleh pengetahuan dari orang lain (Felton dan Berry, 1992). Pengetahuan yang diperoleh dapat berupa bimbingan/arahan, diskusi masalah, maupun pengajaran suatu keterampilan. Dengan adanya informasi tersebut maka individu dapat menyelesaikan masalah yang dihadapi atau memperoleh pengetahuan baru (Weiss dalam Cutrona dan Russel, 1987).

\section{Opportunity for Nurturance}

Bentuk dukungan ini berbeda dengan lima bentuk dukungan sebelumnya. Pada 
dukungan ini, individu justru memberikan bantuan pada orang lain. Ini merupakan kesempatan bagi individu untuk memberikan pertolongan pada orang lain (Cutrona et al., 1994). Pertolongan yang diberikan dapat berupa materi atau jasa. Dengan memberikan pertolongan, individu merasa dibutuhkan oleh orang lain sehingga adanya perasaan bahwa orang lain tergantung padanya.

Uraian mengenai bentuk-bentuk dukungan sosial di atas akan digunakan sebagai acuan dalam melihat dukungan sosial yang diberikan pada anak jalanan di rumah singgah dilts foundation.

Pelayanan sosial merupakan suatu bentuk aktivitas yang bertujuan untuk membantu individu, kelompok, ataupun masyarakat agar mereka mampu memenuhi kebutuhan-kebutuhannya, yang pada akhirnya mereka berharap dapat memecahkan permasalahan yang ada melalui tindakan-tindakan kerja sama atau melalui pemanfaatan sumber-sumber yang ada di masyarakat untuk memperbaiki kondisi kehidupannya. Pelayanan sosial menurut pendapat yang dikatakan oleh Alfred J. Khan dalam Soetarso (1993:26) yaitu sebagai berikut:

"program-program yang dilaksanakan tanpa mempertimbangkan kriteria pasar untuk menjamin suatu tingkat dasar dalam penyediaan fasilitas pemenuhan kebutuhan kehidupan masyarakat serta kemampuan perorangan untuk melaksanakan fungsi-fungsinya untuk memperlancar kemampuan menjangkau dan menggunakan pelayanan serta lembaga yang telah ada dan membantu masyarakat yang mengalami kesulitan dan ketelantaran."

Pelayanan sosial meliputi kegiatan atau intervensi terhadap kasus yang muncul dan dilaksanakan secara langsung dan terorganisir serta memiliki tujuan untuk membantu individu, kelompok, dan lingkungan sosial dalam upaya mencapai penyesuaian dan keberfungsian yang baik dalam segala bidang kehidupan di masyarakat. Hal yang terkandung dalam pelayanan dapat dikatakan adanya kegiatan yang memberikan jasa kepada klien dan membantu mewujudkan tujuan-tujuan mereka. Yayasan Dilts (Dilts Foundation/DF) terbentuk atas kepedulian pasangan suami istri DR. Russel Dilts dan Wahyu Setyowati. Melihat kerasnya kehidupan yang dihadapi oleh anak-anak dari keluarga prasejahtera dengan gizi buruk, sakit, cacat, putus sekolah, serta anak-anak yang terpaksa harus mengais rejeki di jalanan kota-kota besar seperti Jakarta.

Lembaga pelayanan sosial menurut Alfred J. Khan dalam Soetarso (1993:38), memiliki tugas-tugas untuk:

1. Memperkuat dan memperbaiki fungsifungsi keluarga dan perorangan selaras dengan peranan-peranan yang selalu berkembang.

2. Menyediakan saluran kelembagaan baru untuk keperluan sosialisasi, pengembangan dan pemberian bantuan, yaitu peranan-peranan yang masa lampau dilakukan oleh keluarga.

3. Mengembangkan bentuk-bentuk lembaga baru untuk melaksanakan kegiatankegiatan baru yang sangat diperlukan oleh perorangan, keluarga, dan kelompok dalam masyarakat industri dan kota yang kompleks.

Tugas-tugas ini umumya ada dalam lembaga pelayanan sosial untuk membantu masyarakat yang membutuhkan bantuan serta memberikan pelayanan dengan serangkaian kegiatan dalam bidang tertentu yang ditujukan kepada individu, kelompok, dan masyarakat untuk kesejahteraannya. Lembaga-lembaga sosial harus lebih memerhatikan hal-hal yang seharusnya dibutuhkan oleh anak jalanan dalam bersosialisasi, agar sikap dan perilakunya dapat diterima oleh masyarakat banyak.

\section{Simpulan dan Saran (Conclusion and Suggestion) \\ Dari hasil penelitian tinjauan pustaka,} kebutuhan anak jalanan akan dukungan sosial di rumah singgah sangat penting. , dukungan sosial memiliki pengaruh positif pada kesehatan seseorang tanpa memperhatikan tingkat stress individu. Dengan perkataan lain, dukungan sosial dapat melindungi individu baik dalam situasi stress ataupun situasi tidak stress. Dengan adanya dukungan sosial maka kesehatan 
individu baik kesehatan fisik serta mental akan terjaga dan lebih baik.

Dukungan sosial memang suatu kebutuhan yang dibutuhkan oleh individu, entah dalam keadaan terpuruk entah untuk menjadikan dirinya lebih baik lagi. Tidak hanya secara psikologis, dukungan sosial juga memberikan dampak yang lebih dalam. $\mathrm{Hal}$ ini diperkuat dengan pernyataan menurut Sarafino (1994), dukungan sosial tidak hanya menolong pada saat terjadinya stress, tetapi dukungan sosial dapat mengatasi masalah sejak awal.

Dukungan sosial model ini meliputi jaringan sosial yang dimiliki oleh individu. Individu yang terisolasi secara sosial dan memiliki sedikit kesempatan untuk memperoleh dukungan sosial akan memiliki risiko yang lebih besar terganggu kesehatannya (Gottlieb, 1986). Selanjutnya, besar jaringan sosial individu berperan dalam menentukan besarnya dukungan sosial yang diperoleh individu tersebut. semakin luas jaringan sosial yang dimiliki individu maka dukungan sosial yang kemungkinan ia dapat semakin besar. Untuk menerapkan dukungan sosial itu sendiri dibutuhkan bentuk dari dukungan sosial.

\section{Daftar Pustaka}

Armai, Arief. 20002. Rumah Singgah Sebagai Tempat Alternative Pemberdayaan Anak Jalanan. (Jurnal Fajar) Jakarta: LPM UIN. hal. 1

Andari, Soetji, dkk. 2007. Uji Coba Model Perlindungan Anak Jalanan terhadap Tindak Kekerasan. Yogyakarta: B2P3KS.
Depatemen Sosial RI. 2002. Pedoman Penyelenggaraan Pembinaan Anak Jalanan Melalui Rumah Singgah. Jakarta: Direktorat Jenderal Bina Kesejahteraan Sosial, Depertemen Sosial RI.

Direktorat Kesejahteraan Anak, Keluarga, dan Lanjut Usia - Deputi Bidang Peningkatan Kesejahteraan Sosial. 2000. Modul Pelatihan Pimpinan Rumah Singgah. Jakarta: Badan Kesejahteraan Sosial Nasional.

Departemen Sosial RI. 2003. Upaya Pencarian Model yang Efektif dalam Penanganan Anak Jalanan. (Penelitian Universitas Muhammadiyah Jakarta bekerja sama dengan Balitbangsos Departemen Sosial RI)

Gottlieb, B. H. 1988. Social Support Strategies. Guidelines for Mental Health Practices. California: Sage Publishing Co

Gottlieb, B. H. 1988. Marshalling Social Support: Formats, Process, and Effects. New York: Sage Publishing Co

Haditono, Siti Rahayu. 1992. Psikologi Perkembangan, Pengantar dalam berbagai bagiannya. Yogyakarta: Gadjah Mada University Press

Hans O. F. Veiel \& Urs Baumann. The Meaning and Measurement of Social Support. New York: Hemisphere Publish Corp 